\title{
窒素施肥によるオドンチオダの生育・開花促進
}

\author{
窪田 $\quad$ 聡 $^{1 *} \cdot$ 村松嘉幸 ${ }^{1 \mathrm{a}} \cdot$ 松浦真夕美 ${ }^{1} \cdot$ 伊藤真広 ${ }^{1 b} \cdot$ 住吉 $\quad$ 久 $^{2} \cdot$ 腰岡政二 ${ }^{1}$ \\ ${ }^{1}$ 日本大学生物資源科学部 252-8510 藤沢市亀井野 \\ 2 (株) ニチレイガーデン 399-0213 長野県諏訪郡富士見町
}

\section{The Growth and Flowering of Odontioda Orchid are Stimulated by Nitrogen Application}

\author{
Satoshi Kubota ${ }^{1 *}$, Yoshiyuki Muramatsu ${ }^{1 a}$, Mayumi Matsuura ${ }^{1}$, \\ Masahiro Ito $^{1 \mathrm{~b}}$, Hisashi Sumiyoshi ${ }^{2}$ and Masaji Koshioka ${ }^{1}$ \\ ${ }^{I}$ Nihon University, College of Bioresource Science, Kameino, Fujisawa, Kanagawa 252-8510 \\ ${ }^{2}$ Nichirei Garden Inc., Fujimi, Suwa, Nagano 399-0213
}

\begin{abstract}
The effects of nitrogen $(\mathrm{N})$, phosphates $\left(\mathrm{P}_{2} \mathrm{O}_{5}\right)$, and potash $\left(\mathrm{K}_{2} \mathrm{O}\right)$ application on growth and flowering of Odontioda orchid were investigated for two years to demonstrate the optimal amounts of fertilizer for Odontioda potted in bark. $\mathrm{N}$ application caused an increase of dry matter production and leaf area of the current shoot (CS), and an increase in the number of florets; the effects were remarkable at the second year. The optimal amount of $\mathrm{N}$ application was $560 \mathrm{mg} / \mathrm{pot} / \mathrm{year}$ using slow release fertilizer. When Odontioda were grown under the optimal $\mathrm{N}$ application, $\mathrm{N}$ concentration of the final leaf of CS before flowering was $1.86 \%$. Chlorophyll concentration (SPAD) was positively correlated with $\mathrm{N}$ concentration $(r=0.854)$ in the final leaf, $\mathrm{N}$ concentration in the leaf could be estimated easily by measuring chlorophyll concentration (SPAD). The impact of $\mathrm{P}_{2} \mathrm{O}_{5}$ and $\mathrm{K}_{2} \mathrm{O}$ application on growth and flowering was limited, and the application of $240 \mathrm{mg} \mathrm{P}_{2} \mathrm{O}_{5} /$ pot/year and $280 \mathrm{mg} \mathrm{K} 2 \mathrm{O} /$ pot/ year using slow release fertilizer was sufficient for the stable production of Odontioda.
\end{abstract}

Key Words : dry matter production, nutrients, phosphates, potash

キーワード：乾物生産，カリ，リン酸，養分

\section{緒言}

オドンチオダは,メキシコから南米の高地にかけて約 300 種が分布するオドントグロッサムと,アンデス山脈に 5 種が 分布するコクリオーダ（小田，1984）の属間交配種である. オドントグロッサムも含めて, 夏季冷涼なヨーロッパでは非 常に多くの品種が作出され, 主要なランの一つとして親しま れている（唐澤, 1998).オドンチオダの花色は, 黄色や桃 色に加えて, 非常に鮮明な赤色まで非常に幅広く, 花の大き さや花模様も豊富であることから, 消費者の幅広いニーズに 対応できる品目である. また，ファレノプシスのように花茥 を誘引して鉢物として仕立てることができ, 現在やや低迷し ているファレノプシスに代わり得る鉢物としても期待され， 今後生産量が増加する可能性を秘めている.

オドンチオダは複茎性のランであり, 毎年ほぼ 1 本の

2008 年 6 月 12 日 受付. 2008 年 9 月 9 日 受理.

本報告の一部は園芸学会平成 19 年秋季大会で発表した。

* Corresponding author. E-mail: skubota@brs.nihon-u.ac.jp

a現在 : 片倉チッカリン株式会社

b 現在：(有) 椎名洋ラン園
シュートが発生する。 このシュートから 10 枚前後の葉が 発生した後, 偽球茎を形成し, 偽球茎から 1 節下の腋芽が 花茎となり，開花する。高温条件では生育が著しく停滞す る（Kubota ら，2005）ため，わが国では主に高冷地で栽培 されているが，現在のところその生産量は少ない，生産量 を増大させるためには，開花調節に結びつく技術の検討 （窪田ら，2006）に加えて, 温度，光などの基本的な栽培条 件に関する情報（Kubota ら，2005; Yoneda・Suzuki, 1998） が不可欠であるが，施肥に関しては Yonedaら（1999）が ミズゴケ培地による半年間の肥料試験を行っているのみで ある。しかし，現在のオドンチオダの栽培にはミズゴケは ほとんど利用されて抢らず，バークの利用が主体である. 培地の種類によって鉢内の養水分の保持能力が大きく異な ることが知られ（須藤ら，1991），ミズゴケ栽培における最 適水準はバーク栽培には適用できない。 また，オドンチオ ダは出荷まで $2 \sim 3$ 年の栽培期間を要し，かつ複数の偽球 茥を持つことから，偽球茎に貯蔵された養分が次年度に影 響する可能性があり，本種の施肥の効果を明らかにするに は短くとも 2 年間の実験が必要と考えられる.

培地の種類や施肥量が同一でも，植物が利用可能な鉢内 
の養分含有量は灌水方法あるいは鉢の種類によって大きく 異なる（窪田ら，1993; 須藤・篠田，1990）。そのため, 現 在の施肥管理が好適な水準にあるかどらかを判定するため に, 様々な窒素栄養診断法が考案され（福田ら， 2004; 井 上ら，2002; 河合ら，1992)，なかでも葉緑素計を利用した 窒素栄養診断法は非常に簡便である. 従って, オドンチオ ダに抢いても最適な施肥水準に打ける葉緑素濃度と窒素栄 養との相関関係が明らかになれば, 異なる灌水・施肥条件 のもとでも葉緑素計を用いて植物の窒素栄養が随時把握で き，各生産者が効率的な施肥管理を行うことができる.

そこで，本実験ではバーク植えのオドンチオダの生育・ 開花に好適な施肥水準を明らかにするために，2 年間にわ たる窒素, リン酸, カリの施肥量がオドンチオダの生育・ 開花に及活寸影響について検討するとともに，葉緑素計に よる簡易窒素栄養診断が可能かどうか検討した.

\section{材料および方法}

材料は株式会社ニチレイガーデンで栽培していたフラス コ出しから約 1 年半経過した Odontioda Marie Noel 'Velano' を供試した。供試株は 3 号黒ビニルポットにバーク単用植 えにし, 株式会社ニチレイガーデンの温室（長野県富士見 町, 標高 $945 \mathrm{~m}$ ) で管理した. 肥料は窒素として被覆硝酸石 灰 $\left(\mathrm{N}-\mathrm{P}_{2} \mathrm{O}_{5}-\mathrm{K}_{2} \mathrm{O}=12-0-0\right.$, ロングショウカル, 140 日タイプ $)$, リン酸として被覆リンサン $\left(\mathrm{N}-\mathrm{P}_{2} \mathrm{O}_{5}-\mathrm{K}_{2} \mathrm{O}=0-26-0\right.$, 試作品, 180 日タイプ), カリとして被覆硫酸加里 $\left(\mathrm{N}^{-} \mathrm{P}_{2} \mathrm{O}_{5}-\mathrm{K}_{2} \mathrm{O}=0\right.$ 0-40, 試作品, 140 日タイプ) を用いた。 これらの肥料は, チッソ旭肥料株式会社から提供を受けた.

施肥は第 1 表に示すように, 窒素 $(\mathrm{N}$ 区), リン酸（P区） 沶よびカリ（K区）の施肥量をそれぞれ単独に $0 \sim 3 の 4$ 水準で変化させる区を設けた。 このうち，N-1，P-1，K-1 は 同一の処理であるため, 3 区に共通の 1 処理を設定し, 合計 で 10 区とした．繰り返しは 3 反復， 1 反復あたり 6 株を用 い, 全供試株数は 180 株であった. 1 年目の施肥は 2004 年 4 月 7 日に行い, 2 年目は 2005 年 4 月 26 日に 4 号黒ビニル

第 1 表 各実験区の施肥量

\begin{tabular}{cccc}
\hline \hline 区名 $^{\mathrm{z}}$ & $\mathrm{N}(\mathrm{mg} /$ 鉢 $)$ & $\mathrm{P}_{2} \mathrm{O}_{5}(\mathrm{mg} /$ 鉢 $)$ & $\mathrm{K}_{2} \mathrm{O}(\mathrm{mg} /$ 鉢 $)$ \\
\hline $\mathrm{N}-0$ & 0 & 240 & 280 \\
$\mathrm{~N}-1$ & 280 & 240 & 280 \\
$\mathrm{~N}-2$ & 560 & 240 & 280 \\
$\mathrm{~N}-3$ & 840 & 240 & 280 \\
\hline $\mathrm{P}-0$ & 280 & 0 & 280 \\
$\mathrm{P}-1$ & 280 & 240 & 280 \\
$\mathrm{P}-2$ & 280 & 480 & 280 \\
$\mathrm{P}-3$ & 280 & 720 & 280 \\
\hline $\mathrm{K}-0$ & 280 & 240 & 0 \\
$\mathrm{~K}-1$ & 280 & 240 & 280 \\
$\mathrm{~K}-2$ & 280 & 240 & 560 \\
$\mathrm{~K}-3$ & 280 & 240 & 840 \\
\hline
\end{tabular}

${ }^{\mathrm{z}} \mathrm{N}-1, \mathrm{P}-1, \mathrm{~K}-1$ は同一処理であるため, 3区共通で1処理とした
ポットにバーク単用で植え替え後, 前年と同量を施肥した.

実験期間中の栽培管理は当農場の慣行法で行った，温室 内の光強度は $60 \%$ 遮光と $25 \%$ 遮光の遮光ネットを 2 枚組み 合わせて最大 $500 \sim 650 \mu \mathrm{mol} \cdot \mathrm{m}^{-2} \cdot \mathrm{sec}^{-1}$ 確保されるよう に制御し, 温室内気温は最低約 $15^{\circ} \mathrm{C}$ 以上, 最高約 $30^{\circ} \mathrm{C}$ 以 下になるよらに管理した．灌水はスプリンクラーで $3 \sim 4$ 日間隔で行った。

実験開始時に成長しているシュートをカレントシュート (CS)，それより古い世代のシュートをバックシュート（BS） と定義した（窪田ら，2006）。なお，CS は 1 株に 1 本発生 して打り, 複数発生している株はなかった.

2004 年 11 月 16 日と 2006 年 4 月 28 日に CS の葉数と CS の偽球茎の直上に位置している最終葉の葉緑素濃度を葉緑 素計（SPAD-502，ミノルタ）で測定した。 これと同時に各 繰り返しから 1 株ずつサンプリングした。サンプリングし た株は CS の偽球茎と CS の葉，BS と根の 4 つに分割し凍 結乾燥後, 乾物重を測定した。 また, CS の葉の養分含有率 を測定するため，乾物をサリチル硫酸一過酸化水素分解法 により分解し，窒素含有率をインドフェノール法，リン含 有率をモリブデンブルー法, カリウム含有率を原子吸光法 で測定した.

2006 年のサンプリング株については CS の葉面積を計測 した。葉面積は葉長と葉幅の積との間に高い相関関係 $(r=0.989)$ が認められたので, 得られた一次回帰式（葉面 積 $=0.711 \times$ 葉長 $\times$ 葉幅 $+0.965 ）$ を用いて算出した. 開花 率，開花日，小花数は随時調査した．統計処理は年ごとに 分散分析を行い，分散分析に扔いて有意差が認められた項 目についてのみ Tukey の多重検定を行った。

\section{結果}

$\mathrm{CS}$ の葉数は $\mathrm{N}$ 区扣よび $\mathrm{K}$ 区では 1 年目， 2 年目ともに 処理間に差はなかった (第 2 表). P 区では 1 年目の P-1 で 他の水準よりもわずかに多くなった． 2 年目の葉面積は N0 で著しく小さく, N-2 まで施肥量が増加するに従って拡 大した， $\mathrm{P}$ 区と K 区には処理間に差はなかった，最終葉の 葉緑素濃度は 1 年目, 2 年目ともに N-0 で著しく低下した. $\mathrm{P}$ 区と K 区には差はなかった。 また，全体的に 2 年目の葉 緑素濃度は 1 年目に比べて低下していた。

$\mathrm{CS}$ の偽球茎と葉の乾物重は 1 年目では $\mathrm{N}$ 区間に差はな かったが, 2 年目になると N-0 で著しく減少した (第 3 表). BS と根の乾物重には 1 年目, 2 年目ともに差はなかった. 1 年目の全乾物重は $\mathrm{N}-0$ と N-2 の間で有意差があり, N-0 で少なかった． 2 年目では N-0 では他の区に比べると少な い傾向があったものの，反復間のばらつきが比較的大き かったため水準間に有意差はなかった.

$\mathrm{P}$ 区と K 区の乾物重は, いずれの部位においても 1 年目, 2 年目ともに処理間に有意差はなかった（第 4,5 表）.

$\mathrm{N}$ 区の開花率は 1 年目, 2 年目ともに N-0 で低くなる傾 向にあったが，反復間のばらつきが比較的大きかったた 
第 2 表 オドンチオダの CS の葉数, 葉面積, 葉緑素濃度に及ぼす施肥の影響

\begin{tabular}{|c|c|c|c|c|c|c|c|c|c|c|}
\hline \multirow{2}{*}{ 年 } & \multirow{2}{*}{$\begin{array}{l}\text { 施肥 } \\
\text { 水準 }\end{array}$} & \multicolumn{3}{|c|}{ 葉数（枚／個体） } & \multicolumn{3}{|c|}{ 葉面積（$\left(\mathrm{cm}^{2} /\right.$ 個体 $)$} & \multicolumn{2}{|c|}{ 最終葉の葉緑素濃度 } & \multirow{2}{*}{$\begin{array}{r}\text { (SPAD) } \\
\text { K 区 }\end{array}$} \\
\hline & & $\mathrm{N}$ 区 & $\mathrm{P}$ 区 & K 区 & $\mathrm{N}$ 区 & P 区 & K 区 & $\mathrm{N}$ 区 & $\mathrm{P}$ 区 & \\
\hline \multirow{5}{*}{1 年目 } & 0 & 7.6 & $7.1 \mathrm{~b}^{\mathrm{y}}$ & 7.2 & - & - & - & $46.2 \mathrm{~b}$ & 63.7 & 65.6 \\
\hline & 1 & 7.6 & $7.6 \mathrm{a}$ & 7.6 & - & - & - & $67.6 \mathrm{a}$ & 67.6 & 67.6 \\
\hline & 2 & 7.7 & $7.2 \mathrm{~b}$ & 7.4 & - & - & - & $69.7 \mathrm{a}$ & 72.8 & 69.9 \\
\hline & 3 & 7.6 & $7.3 \mathrm{~b}$ & 7.3 & - & - & - & $70.2 \mathrm{a}$ & 69.5 & 71.2 \\
\hline & 有意差 ${ }^{z}$ & N.S. & $*$ & N.S. & - & - & - & $*$ & N.S. & N.S. \\
\hline \multirow{5}{*}{2 年目 } & 0 & 4.3 & 5.3 & 5.0 & $122.3 \mathrm{c}$ & 373.6 & 363.2 & $32.1 \mathrm{~b}$ & 62.8 & 51.2 \\
\hline & 1 & 6.0 & 6.0 & 6.0 & $321.0 \mathrm{~b}$ & 321.0 & 321.0 & $60.1 \mathrm{a}$ & 60.1 & 60.1 \\
\hline & 2 & 6.0 & 5.3 & 5.3 & $449.2 \mathrm{a}$ & 450.6 & 417.1 & $59.8 \mathrm{a}$ & 63.4 & 68.0 \\
\hline & 3 & 5.3 & 5.3 & 6.0 & $469.9 \mathrm{a}$ & 435.4 & 392.5 & $68.4 \mathrm{a}$ & 42.8 & 64.2 \\
\hline & 有意差 ${ }^{z}$ & N.S. & N.S. & N.S. & $* *$ & N.S. & N.S. & $*$ & N.S. & N.S. \\
\hline
\end{tabular}

$\mathrm{z}$ 分散分析により，**は 1\%,**は 5\%の危険率で有意差あり， N.S. は有意差なしを示す

${ }^{\mathrm{y}}$ Tukey の多重検定により，異なる符号間には 5\%の危険率で有意差ありを示す

第 3 表 オドンチオダの乾物重に及ぼす窒素施肥の影響

\begin{tabular}{|c|c|c|c|c|c|c|}
\hline 年 & 区 & $\begin{array}{c}\mathrm{CS} \text { の偽球茎 } \\
(\mathrm{g} / \text { 個体 })\end{array}$ & $\begin{array}{c}\mathrm{CS} \text { の葉 } \\
(\mathrm{g} / \text { 個体 })\end{array}$ & $\begin{array}{c}\mathrm{BS} \\
(\mathrm{g} / \text { 個体 })\end{array}$ & $\begin{array}{c}\text { 根 } \\
(\mathrm{g} / \text { 個体 })\end{array}$ & $\begin{array}{c}\text { 全体 } \\
(\mathrm{g} / \text { 個体 })\end{array}$ \\
\hline \multirow{5}{*}{1 年目 } & $\mathrm{N}-0$ & 2.02 & 2.47 & 4.89 & 1.63 & $11.01 \mathrm{~b}$ \\
\hline & $\mathrm{N}-1$ & 2.49 & 3.49 & 4.61 & 2.22 & $12.81 \mathrm{ab}$ \\
\hline & $\mathrm{N}-2$ & 2.59 & 3.64 & 5.59 & 2.13 & $13.95 \mathrm{a}$ \\
\hline & $\mathrm{N}-3$ & 2.11 & 3.09 & 4.78 & 1.87 & $11.83 \mathrm{ab}$ \\
\hline & 有意差 ${ }^{z}$ & N.S. & N.S. & N.S. & N.S. & $*$ \\
\hline \multirow{5}{*}{2 年目 } & $\mathrm{N}-0$ & $1.34 \mathrm{~b}^{\mathrm{y}}$ & $1.21 \mathrm{c}$ & 7.01 & 2.40 & 11.95 \\
\hline & N-1 & $3.41 \mathrm{a}$ & $3.51 \mathrm{~b}$ & 9.58 & 3.18 & 19.68 \\
\hline & $\mathrm{N}-2$ & $2.87 \mathrm{a}$ & $4.91 \mathrm{ab}$ & 11.60 & 3.73 & 23.11 \\
\hline & $\mathrm{N}-3$ & $3.79 \mathrm{a}$ & $5.36 \mathrm{a}$ & 9.35 & 2.71 & 21.20 \\
\hline & 有意差 ${ }^{z}$ & $* *$ & $* *$ & N.S. & N.S. & N.S. \\
\hline
\end{tabular}

z 分散分析により, **は 1\%,*は 5\%の危険率で有意差あり， N.S. は有意差なしを示す

${ }^{\mathrm{y}}$ Tukey の多重検定により，異なる符号間には $5 \%$ の危険率で有意差ありを示す

第 4 表 オドンチオダの乾物生産に及ぼすリン酸施肥の影響

\begin{tabular}{|c|c|c|c|c|c|c|}
\hline 年 & 区 & $\begin{array}{c}\mathrm{CS} \text { の偽球茥 } \\
(\mathrm{g} / \text { 個体 })\end{array}$ & $\begin{array}{c}\mathrm{CS} \text { の葉 } \\
(\mathrm{g} / \text { 個体 })\end{array}$ & $\begin{array}{c}\mathrm{BS} \\
(\mathrm{g} / \text { 個体 })\end{array}$ & $\begin{array}{c}\text { 根 } \\
(\mathrm{g} / \text { 個体 })\end{array}$ & $\begin{array}{c}\text { 全体 } \\
\text { (g / 個体) }\end{array}$ \\
\hline \multirow{5}{*}{1 年目 } & $\mathrm{P}-0$ & 1.81 & 2.83 & 3.93 & 1.54 & 10.12 \\
\hline & P-1 & 2.49 & 3.49 & 4.61 & 2.22 & 12.81 \\
\hline & P-2 & 1.96 & 2.88 & 3.47 & 1.60 & 9.86 \\
\hline & P-3 & 1.56 & 2.73 & 3.65 & 1.78 & 9.72 \\
\hline & 有意差 z & N.S. & N.S. & N.S. & N.S. & N.S. \\
\hline \multirow{5}{*}{2 年目 } & $\mathrm{P}-0$ & 2.80 & 3.94 & 7.74 & 2.91 & 17.40 \\
\hline & P-1 & 3.41 & 3.51 & 9.58 & 3.18 & 19.68 \\
\hline & P-2 & 2.90 & 5.00 & 8.03 & 3.64 & 20.58 \\
\hline & P-3 & 1.78 & 4.96 & 7.86 & 2.98 & 17.58 \\
\hline & 有意差 ${ }^{z}$ & N.S. & N.S. & N.S. & N.S. & N.S. \\
\hline
\end{tabular}

z 分散分析により, N.S. は有意差なしを示す

め水準間に有意差はなかった（第 6 表）. P 区と K 区の開 花率には処理間に差はなかった. $\mathrm{N}$ 区の小花数は 1 年目, 2 年目ともに N-0 で明らかに少なく, N-2 で多くなる傾向が 見られた. 1 年目と 2 年目の小花数を比較すると N-0 では 8.2 輪から 5.5 輪とやや減少するが, N-1, N-2, N-3では 1 年目に $10.8 \sim 14.2$ 輪であったのに対して, 2 年目は $18.7 〜$ 27.7 輪と 1 年目の約 2 倍に増加し, N-0 とその他の水準と
の差は 2 年目により顕著となった. $\mathrm{P}$ 区の小花数は処理間 に差はなかった，K区の小花数は 1 年目では K-0 と K-2 の 間で有意差があり，K-0 で少なかった， 2 年目には差は見 られなかった。開花日はいずれの区においても差はなかっ た (データ略).

CS の最終葉の窒素含有率は 1 年目では窒素施肥量が N2 まで増加するに伴い高くなり，2 年目は N-0 で他の区に 
第 5 表 オドンチオダの乾物生産に及ぼすカリ施肥の影響

\begin{tabular}{|c|c|c|c|c|c|c|}
\hline 年 & 区 & $\begin{array}{c}\text { CS の偽球茥 } \\
(\mathrm{g} / \text { 個体 })\end{array}$ & $\begin{array}{c}\mathrm{CS} \text { の葉 } \\
(\mathrm{g} / \text { 個体 })\end{array}$ & $\begin{array}{c}\mathrm{BS} \\
(\mathrm{g} / \text { 個体 })\end{array}$ & $\begin{array}{c}\text { 根 } \\
\text { (g / 個体) }\end{array}$ & $\begin{array}{c}\text { 全体 } \\
\text { (g/個体) }\end{array}$ \\
\hline \multirow{5}{*}{1 年目 } & K-0 & 1.58 & 2.65 & 4.87 & 1.88 & 10.98 \\
\hline & K-1 & 2.49 & 3.49 & 4.61 & 2.22 & 12.81 \\
\hline & $\mathrm{K}-2$ & 1.99 & 3.25 & 3.93 & 1.72 & 10.88 \\
\hline & $\mathrm{K}-3$ & 2.44 & 3.20 & 5.17 & 2.01 & 12.84 \\
\hline & 有意差 ${ }^{z}$ & N.S. & N.S. & N.S. & N.S. & N.S. \\
\hline \multirow{5}{*}{2 年目 } & K-0 & 2.51 & 3.99 & 8.38 & 3.88 & 18.75 \\
\hline & $\mathrm{K}-1$ & 3.41 & 3.51 & 9.58 & 3.18 & 19.68 \\
\hline & $\mathrm{K}-2$ & 2.68 & 4.08 & 8.78 & 2.61 & 18.14 \\
\hline & $\mathrm{K}-3$ & 2.74 & 4.45 & 9.21 & 4.14 & 20.53 \\
\hline & 有意差 ${ }^{z}$ & N.S. & N.S. & N.S. & N.S. & N.S. \\
\hline
\end{tabular}

z 分散分析により, N.S. は有意差なしを示す

第 6 表 開花に及ぼす施肥の影響

\begin{tabular}{|c|c|c|c|c|c|c|c|}
\hline \multirow{2}{*}{ 年 } & \multirow{2}{*}{ 施肥水準 } & \multicolumn{3}{|c|}{ 開花率（\%) } & \multicolumn{3}{|c|}{ 小花数（輪／株） } \\
\hline & & N区 & P 区 & K 区 & N区 & $\mathrm{P}$ 区 & K 区 \\
\hline \multirow{5}{*}{1 年目 } & 0 & 33.3 & 55.6 & 44.4 & $8.2 \mathrm{~b}^{\mathrm{y}}$ & 10.9 & $7.5 \mathrm{~b}$ \\
\hline & 1 & 61.1 & 61.1 & 61.1 & $10.8 \mathrm{~b}$ & 10.8 & $10.8 \mathrm{ab}$ \\
\hline & 2 & 66.7 & 27.8 & 55.6 & $14.2 \mathrm{a}$ & 9.2 & $11.7 \mathrm{a}$ \\
\hline & 3 & 72.2 & 55.6 & 88.9 & $11.8 \mathrm{ab}$ & 10.9 & $10.8 \mathrm{ab}$ \\
\hline & 有意差 ${ }^{\mathrm{z}}$ & N.S. & N.S. & N.S. & $* *$ & N.S. & $*$ \\
\hline \multirow{5}{*}{2 年目 } & 0 & 26.7 & 73.3 & 60.0 & $5.5 \mathrm{~b}$ & 14.1 & 13.7 \\
\hline & 1 & 66.7 & 66.7 & 66.7 & $18.7 \mathrm{ab}$ & 18.7 & 18.7 \\
\hline & 2 & 46.7 & 80.0 & 93.3 & $27.7 \mathrm{a}$ & 15.6 & 16.9 \\
\hline & 3 & 60.0 & 53.3 & 46.7 & $25.2 \mathrm{a}$ & 15.7 & 15.8 \\
\hline & 有意差 ${ }^{z}$ & N.S. & N.S. & N.S. & $* *$ & N.S. & N.S. \\
\hline
\end{tabular}

z 分散分析により，**は $1 \%, *$ * 5\%の危険率で有意差あり, N.S. は有意差なしを示す

${ }^{\mathrm{y}}$ Tukey の多重検定により異なる符号間には 5\%の危険率で有意差ありを示す

第 7 表 CS の最終葉の養分含有率に及ぼす施肥の影響

\begin{tabular}{|c|c|c|c|c|c|c|c|c|c|c|}
\hline \multirow{2}{*}{ 年 } & \multirow{2}{*}{$\begin{array}{l}\text { 施肥 } \\
\text { 水準 }\end{array}$} & \multicolumn{3}{|c|}{$\mathrm{N}(\%)$} & \multicolumn{3}{|c|}{$\mathrm{P}(\%)$} & \multicolumn{3}{|c|}{ K $(\%)$} \\
\hline & & N区 & P 区 & K区 & N 区 & P 区 & K 区 & N区 & P 区 & K 区 \\
\hline \multirow{5}{*}{1 年目 } & 0 & $1.32 \mathrm{~b}^{\mathrm{y}}$ & 1.60 & 1.52 & 0.30 & 0.26 & 0.30 & 4.78 & 4.23 & $3.98 \mathrm{~b}$ \\
\hline & 1 & $1.65 \mathrm{ab}$ & 1.65 & 1.65 & 0.35 & 0.35 & 0.35 & 5.02 & 5.02 & $5.02 \mathrm{a}$ \\
\hline & 2 & $1.86 \mathrm{a}$ & 1.54 & 1.56 & 0.33 & 0.31 & 0.31 & 5.22 & 5.01 & $5.32 \mathrm{a}$ \\
\hline & 3 & $1.87 \mathrm{a}$ & 1.62 & 1.72 & 0.29 & 0.28 & 0.35 & 6.10 & 5.21 & $5.52 \mathrm{a}$ \\
\hline & 有意差 ${ }^{\mathrm{z}}$ & * & N.S. & N.S. & N.S. & N.S. & N.S. & N.S. & N.S. & $* *$ \\
\hline \multirow{5}{*}{2 年目 } & 0 & $0.71 \mathrm{~b}$ & 1.18 & 1.02 & 0.15 & 0.15 & 0.18 & 1.92 & 2.61 & $1.69 \mathrm{c}$ \\
\hline & 1 & $1.21 \mathrm{a}$ & 1.21 & 1.21 & 0.22 & 0.22 & 0.22 & 2.25 & 2.25 & $2.25 \mathrm{~b}$ \\
\hline & 2 & $1.50 \mathrm{a}$ & 1.27 & 1.29 & 0.22 & 0.24 & 0.25 & 2.40 & 2.23 & $2.83 \mathrm{a}$ \\
\hline & 3 & $1.47 \mathrm{a}$ & 0.97 & 1.16 & 0.23 & 0.19 & 0.19 & 2.46 & 1.85 & $2.60 \mathrm{a}$ \\
\hline & 有意差 ${ }^{z}$ & $* *$ & N.S. & N.S. & N.S. & N.S. & N.S. & N.S. & N.S. & $* *$ \\
\hline
\end{tabular}

z 分散分析により，**は 1\%，*は5\%の危険率で有意差あり， N.S. は有意差なしを示す

${ }^{\mathrm{y}}$ Tukey の多重検定により異なる符号間には 5\%の危険率で有意差ありを示す

比べて明らかに低かった（第 7 表）。P区と $\mathrm{K}$ 区の窒素含 有率はいずれも水準間には差はなかった。リン含有率は $\mathrm{N}$ 区， $\mathrm{P}$ 区， $\mathrm{K}$ 区のいずれの水準間でも差はなかった。 カリ ウム含有率は $\mathrm{N}$ 区と $\mathrm{P}$ 区では水準間に差はなかった，K区 では 1 年目では K-0 で明らかに低く，2 年目はK-2 までカ リ施肥量が増加するに伴い高くなった，窒素，リン，カリ
ウム含有率はいずれの処理区においても 1 年目から 2 年目 にかけて低下する傾向が見られた。

$\mathrm{CS}$ の最終葉の窒素含有率と葉緑素濃度との間には, 一次 回帰式で示される高い相関関係 $(r=0.854)$ が認められた (第 1 図). 


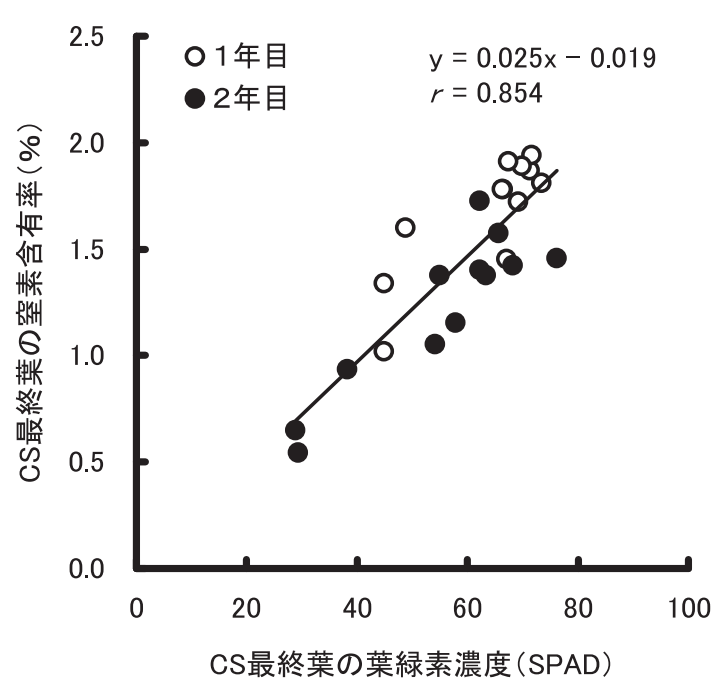

第 1 図 カレントシュート（CS）の最終葉の窒素含有率と葉緑 素濃度 (SPAD) との関係

\section{考察}

$\mathrm{CS}$ の葉数は 1 年目の $\mathrm{P}$ 区を除いて，処理間に有意差は 全くなかった. 通常, 多くの植物で窒素施肥は葉の展開を 促進するが，オドンチオダではそのような現象は観察され なかった. オドンチオダと同様に, 複茎性で偽球茎を形成 するシンビジウムの場合, 窒素施肥量を変えてもシュート の葉数はほとんど変化しない(中野ら, 1977; 新美ら, 1985). また, Kubota ら（2005）がオドンチオダの生育・開花に及 ぼす光強度と温度の影響について検討した報告でも, 葉数 はいずれの処理に扣いても差がなかった，従って，オドン チオダのシュートの葉数は，遺伝的な要因によって規定さ れているか，またはシンビジウムのように将来シュートと なる腋芽ではすでに葉の分化が皃浣了している（大野， 1996）ため，環境条件の違いが現れにくいものと考えられ る. 一方, 2 年目の葉面積は窒素施肥量が増加すると N-2 まで直線的に増加した. CS の偽球茎と葉の乾物重は 1 年 目では N 区間に差はなかったものの，2 年目には N-1 以上 の施肥量で増加した。. また， $\mathrm{N}$ 区の 1 年目から 2 年目にか けての全乾物重の増加量を概算すると, N-0 では $1 \mathrm{~g} /$ 株 以下, N-1 では約 $6 \mathrm{~g} /$ 株, N-2 と N-3では約 $10 \mathrm{~g} /$ 株で あった. 従って, オドンチオダの生育に対する窒素の効果 は 1 年目よりも 2 年目において顕著に現れ, N-2 の窒素施 肥量が生育に対して好適であると考えられる.

開花率は N 区間に差はないものの，N-0で低くなる傾向 にあった. 小花数は 1 年目, 2 年目ともに N-0 で少なく, $\mathrm{N}-2$ で最も多くなった. さらに，2 年目の小花数は N-0を 除くと 1 年目に比べて約 2 倍に増加し, 窒素施肥の効果は 2 年目に拈いて顕著となった. 以上のことから, バーク植 えのオドンチオダの生育と開花は, 緩効性肥料を用いる場 合， N-2 の窒素施肥量（560 mg / 鉢／年）が最適であると 判断できる.
一方，生育・開花に対するリン酸とカリの影響は限定的 であり，P-0 では 1 年目に葉数がやや減少, K-0 では小花数 が減少する程度であり, 顕著な促進的効果は見られなかっ た. ミズゴケ植えのファレノプシスの生育・開花と光合成 に及ぼす窒素, リン酸, カリの影響について検討した報告 （米田ら，1997）では，リン酸無施肥では，試験開始から数 か月で下葉が赤紫色に変色し枯れ上がること，またカりが 不足すると小花数がやや減少し, 個葉の光合成速度が低下 することが明らかとなっている，ファレノプシスでは数か 月の試験に打いてリン酸とカリの明確な欠乏症が発生した のに対し，オドンチオダでは 2 年間にわたる試験において もそのよらな症状は観察されなかった，従って，オドンチ オダのリン酸とカリの要求量はファレノプシスに比べて, 少ないものと思われる.

洋ラン栽培に利用されている各種培地でドリテノプシス を栽培し, 栽培終了後から 11 週間蒸留水で培地中のイオン 放出量を測定した結果（金・市橋，2002）では，ニュージー ランド産バークの $\mathrm{K}^{+}$イオン放出量はニュージーランド産 ミズゴケに比べて著しく多い。また，バークの窒素含有量 はミズゴケ由来のピートとほとんど変わらないが, リンと カリウム含有量は，ミズゴケ由来のピートに比べて 10 倍以 上多い（Bunt, 1988）ことが明らかとなっており，P-0 と K0 に打いても培地として利用したバークからある程度のリ ン酸とカリが供給されていたと推測される，従って，生育 と開花に対してリン酸とカリの影響が顕著に現れなかった のは, オドンチオダのリン酸とカリの要求量が少ない可能 性と, 培地に使用したバークから一定量のリン酸とカリが 供給されていた可能性が考えられる．以上のことから，本 実験のよらなバーク栽培の場合は，実用的には窒素，リン 酸, カリを緩効性肥料として，それぞれ $560 \mathrm{mg} /$ 鉢 / 年, $240 \mathrm{mg} /$ 鉢 / 年, $280 \mathrm{mg} /$ 鉢 /年の施肥量が妥当と判断 できる.

$\mathrm{CS}$ の最終葉の養分含有率はいずれの養分ともに 1 年目よ りも2 年目で低下した。一般に，植物の成長が進むほど乾 物生産量が相対的に増加するため, 無機養分含有率は低下 する傾向にある．これに加えて，本実験のサンプリング時 期は 1 年目では開花前， 2 年目では開花した花茥の収穫後 であった. オドンチオダの花茎と小花の窒素, リン, カリ ウム含有率は，それぞれ約 $2 \% ， 1 \% ， 10 \%$ であり，特にリ ンとカリウム含有率は他の部位に比べて著しく高い（未発 表).すなわち， 2 年目の養分含有率が 1 年目よりも低下し たのは，これらの養分が葉などの栄養体から花茥と小花に 多く移行した結果であると考えられる.

開花前にサンプリングを行った 1 年目の最終葉の窒素含 有率は，生育・開花が抑制された N-0 では $1.32 \%$ と低く，

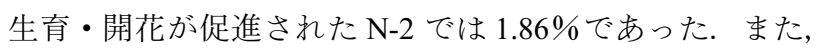
リン含有率は施肥処理間に差はなく, CS の最終葉における リン含有率は $0.3 \%$ 前後であった. 小花数が減少した K-0 に おける CS の最終葉のカリウム含有率は $3.98 \%$ で，小花数 
が増加した K-1 では 5\%を超えた。従って, 生育と開花の 促進には開花前の CS の最終葉の窒素, リン, カリウム含 有率が，それぞれ約 1.8\%, 約 $0.3 \%$, 約 5\%確保されるこ とが望ましい。

本実験では葉緑素計で測定した葉緑素濃度（SPAD）と葉 の窒素含有率との間には一次回帰直線（ $\mathrm{y}=0.025 \mathrm{x}-0.019 ）$ で示される高い相関関係 $(r=0.854)$ が認められ, 葉の葉 緑素濃度を測定することにより，窒素含有率の予測が可能 であった.この一次回帰式に上記に示した最適窒素含有率 を代入すると，葉の葉緑素濃度（SPAD）は約 75 となった。 従って, 使用する培地の種類や灌水方法が本実験とは異 なっても，CS の最終葉の葉緑素濃度を約 75 飞維持するよ ら施肥管理を行らことにより, 生育促進と小花数の増加が 達成されると考兄られる。

\section{摘 要}

バーク植えのオドンチオダの生育と開花に好適な施肥量 を明らかにするために，2 年間にわたって生育と開花に対 する窒素, リン酸, カリ施肥の影響について検討した，窒 素施肥は成長中のカレントシュート (CS) の乾物重の増加, 葉面積の拡大抢よび小花数の増加をもたらし，その効果は 2 年目で顕著になった. $\mathrm{N}$ の最適施肥水準は緩効性肥料と して $560 \mathrm{mg} /$ 鉢/年と判断された. 生育と開花が最も促 進された CS の最終葉の窒素含有率は $1.86 \%$ であった. CS の最終葉の葉緑素濃度 (SPAD) と窒素含有率との間には高 い相関関係 $(r=0.854)$ があり, 最終葉の SPAD 值から葉 の窒素含有率を予測することが可能であった. 生育と開花 に対するリン酸とカリの影響は汪とんぞなく、リン酸とカ リは緩効性肥料としてそれぞれ $240 \mathrm{mg} /$ 鉢/年と $280 \mathrm{mg}$ /鉢／年程度の施肥量で十分であった。

\section{引用文献}

Bunt, A. C. 1988. Media and mixes for container-grown plants. p. 22. Unwin Hyman Ltd., London.

福田 敬・松村 司・山口祐輔 -三好利臣. 2004. 夏秋ギ ク「岩の白扇」の葉身汁液による窒素栄養診断のため の最適葉位と診断指標. 土肥誌. 75: 487-491.

井上惠子・小林泰生・荒木雅登. 2002. シクラメン栽培に

扣ける栄養診断技術（1）葉柄搾汁液硝酸イオン濃度の

簡易測定法. 福岡農総試研報. 21:25-29.

唐澤耕司. 1998. オドントグロッサム．p. 375-376. 農業技

術体系花卉編12. 農文協. 東京.

河合敏彦・長谷川清善・保科次雄. 1992. 夏秋型スプレー
ギクの養分吸収特性预よび葉緑素計による栄養診断. 園学雑. 61 (別1)：494-495.

寉田 聡・金子由恵・高橋 愛・松浦真夕美 - 逆井 肇 渡部一夫・伊藤真広. 2006. オドンチオダの茎頂切除 によるシュート発生時期の斉一化. 園学研. 5: 165-169. 宔田 聡・加藤哲郎・米田和夫. 1993. ファレノプシスの 生育に敃よぼす施肥ならびにミズゴケと素焼鉢の理化 学性の影響. 園学雑. 62: 601-609.

Kubota, S., J. Yamamoto, Y. Takazawa, H. Sakasai, K. Watanabe, K. Yoneda and N. Matsui. 2005. Effects of light intensity and temperature on growth, flowering and single-leaf $\mathrm{CO}_{2}$ assimilation in Odontioda Orchid. J. Japan. Soc. Hort. Sci. 74: $330-336$.

中野 直・片岡虎夫・山口省吾. 1977. 洋らん（シンビジ ウム）の開花調節に関する試験 チッ素の施肥量抢よ び施肥方法が生育・開花に及湆す影響. 三重県農技研 報. 6: 57-66.

新美善行・栗原 広・興梠育良. 1985. ラン科植物の発育 と開花に関する研究 II. 施肥条件の違いがシンビ ジュームの一年生苗の発育に及洔寸影響. 広島農短大 報. 7: 495-506.

小田善一郎. 1984. 洋ラン 品種・育種・栽培・繁殖. p. 309312. 博友社. 東京.

大野 始. 1996. シンビジウム 栽培の基礎生育と生理・ 生態. p. 83-88. 農業技術体系花卉編12. 農文協. 東京. 須藤憲一・伊藤秀和・篠田浩一. 1991. ラン栽培培地内の 養分の予測. 園学雑. 60 (別2)：490-491.

須藤憲一・篠田浩一. 1990. ラン栽培培地内の養水分状態 に打上ぼす潅水施肥方法の影響. 野菜茶試花き部年報. 5: 80-82.

金勲・市橋正一. 2002. 植光込及材料からのイオン放 出と培養液からのイオン吸収並びにドリテノプシスの 生育について. 園学雑. 71:434-440.

Yoneda, K. and N. Suzuki. 1998. Effects of temperature and light intensity on the growth and flowering of Odontoglossum intergeneric hybrids. J. Japan. Soc. Hort. Sci. 67: 619-625.

Yoneda, K., N. Suzuki and I. Hasegawa. 1999. Effects of macroelement concentrations on growth, flowering, and nutrient absorption in an Odontoglossum hybrid. Sci. Hortic. 80: 259-265.

米田和夫・且井真理子・羅田 聡. 1997. ファレノプシス の生育・開花に及ぼす養分欠之の影響とその症状につ いて. 園学雑. 66: 141-147. 